Ewa Rojewska, PhD, https:/ / orcid.org/0000-0003-3988-810X

Institute of Pedagogy,

Department of History and Theory of Education

University of Szczecin

\title{
Loneliness, Solitude and Isolation in the Family as Conceptualised by Jesper Juul
}

\section{Samotność i osamotnienie w rodzinie w ujęciu Jespera Juula}

\author{
https://doi.org/10.34766/ fetr.v47i3.802
}

\begin{abstract}
This article presents an analysis of the theory of relations and upbringing in the family as conceived by Jesper-Juul, whereby the focal point of the study rests on solitude, loneliness and isolation. The research was conducted using an analytical-synthetic method elaborated on the basis of the works of this pedagogue and therapist.

The obtained results indicate an ontological dimension of loneliness in the family, and the need for its prior experience to guarantee one's capacity to forge satisfying future relationships. The analysis of Juul's work leads to the conclusion that solitude and loneliness experienced in the family promote emotional growth of partners and that of the child. The work further focuses on destructive loneliness, i.e. isolation. The predominant conclusion drawn therefrom is that solitude and loneliness in the family carry a relationship-building potential. In the era of the COVID-19 pandemic, undertaking an in-depth analysis of this problem is particularly justified.
\end{abstract}

Key words: isolation in the family, Jesper Juul, family, loneliness and solitude in the family

Abstrakt: Artykuł stanowi oryginalną analizę teorii relacji i wychowania w rodzinie Jespera Juula w perspektywie samotności i osamotnienia, dokonaną $\mathrm{w}$ oparciu o metodę analityczno-syntetyczną na kanwie prac pedagoga i terapeuty rodzin. Uzyskane wyniki badań wskazują na ontologiczny wymiar samotności $w$ rodzinie, potrzebę jej uprzedniego doświadczenia dla jakości tworzonych relacji. Analizy twórczości Juula prowadzą do wniosku, że doświadczenie samotności sprzyja rozwojowi partnerów $\mathrm{w}$ rodzinie oraz rozwojowi dziecka. W pracy wskazuje się również na przejawy destrukcyjnej samotności, czyli osamotnienia w rodzinie. Najważniejsze wnioski prowadzą do konkluzji, że samotność w rodzinie ma moc relacjotwórczą. Artykuł stanowi wkład w pogłębione rozumienie problematyki samotności i osamotnienia $\mathrm{w}$ rodzinie. $\mathrm{W}$ dobie pandemii COVID-19 podjęcie analizy tego problemu jest szczególnie uzasadnione.

Słowa kluczowe: Jesper Juul, osamotnienie w rodzinie, samotność w rodzinie

\section{Inroduction}

Jesper Juul (1948 - 2019) was a Danish family therapist and pedagogue. His work gained him international recognition from both parents and scholars. His books have been translated into over a dozen languages. The work of Jesper Juul seems to be of paramount and truly ground-breaking importance when it comes to the perception of relationships in the family unit and, in particular, with the regard to the relationship unfolding between parents and children. This educationalist is credited with creating a new educational 
paradigm based on the transition from obedience to responsibility ${ }^{1}$. Following an in-depth analysis of Juul's work, one may venture to formulate a thesis which holds the Danish therapist as the creator of pedagogy of family relations in itself. Juul combines theory and practice relating to family life in a hitherto unprecedented way for pedagogy. The term "upbringing" is deliberately avoided in this approach. Juul's concept of supporting the development of a child in the family unit (or actually supporting the development of each family member, regardless of their age) goes far beyond what is commonly understood in pedagogy under the term "upbringing" in (Salamucha, 2004). Jesper Juul outlines the principles and the foundations of family life, which are aimed at safeguarding the well-being of both individual family members and the family as a whole. He then shows how these foundations determine the daily functioning of families. One of the spaces present in the lives of families - and one which is also linked to their well-being - is the space of loneliness and solitude.

The aim of the article is to analyse the essence and meaning of the space of loneliness and solitude, while also shedding light on the dangers of loneliness in the family, as conceptualised by Jesper Juul. The following research problems have been adopted: What is the essence and meaning of loneliness and solitude in the family, as defined in the works of Jesper Juul? What are the spaces of solitude in the family as perceived by Jesper Juul? What are the dangers posed by isolation within the family system, as conceptualised by Jesper Juul? The article was written based on the analytical and synthetic method, which had been elaborated on the basis of the works of Jesper Juul (in their respective Polish translations).

\section{Loneliness and Solitude in the Family - Introduction}

Loneliness in the family is not an individual matter, but an issue that impacts the entire community. The quality of the functioning of the family as a whole, as well as of its individual members, depends on the qualitative manner in which the space of solitude is utilised in the family. As argued by M. Wałejko on philosophical grounds, loneliness and solitude (as well as isolation) are personal existential states of a human being (Wałejko, 2017). Following T. Gadacz, the Author adds that "loneliness is an inseparable part of human nature and existence. To be a person means to be lonely and independent". So being lonely, nowadays, often viewed pejoratively, especially in the context of family life and children's development, is in fact a natural state for human beings. Moreover, the experience of loneliness determines the quality of relationships built with other people. E. Lévinas proved that (ontological) loneliness does not result from breaking up a relationship, but rather, it precedes every new relationship (Kulig, 2014). Nevertheless, the very way in which loneliness is experienced (on a psychological level) by specific individuals may vary. It

${ }^{1}$ http://www.family-lab.pl/jesper-juul/, accessed on: 11/08/2020. 
depends, among other factors, on the meaning ascribed to loneliness and solitude by individual persons.

Jesper Juul's works tackle both of the above-specified dimensions of solitude: the ontological (the existential) one and the psychological one. The former is source-based: its adoption (implicite) results in an affirmative perception of solitude in the psychological dimension (explicite). For Jesper Juul, solitude is one's ally in the process of personal development.

\section{Solitude Conducive to the Development of Partners in the Family}

Change is a natural part of life. It is also a natural feature of any love relationship. This changeability of the facets of love results from the intrinsic nature of the love relationship and of love itself (Wojciszke, 2010). Hence, one could venture a statement that love relationships are subject to periodisation. According to Juul, in the first 7 years of the relationship, the collective identity of "us" dominates over the separate identity of "me and you". And so, the partners feel a strong unity with each other or strive to achieve it, as if experiencing or seeking to experience full union and oneness with their partner; as Juul phrases it, they wish to experience a "mutual fusion" (Juul, Øien, 2012, p. 46). However, the growth of love and the process of personal development of the partners both require the experience of a crisis of this unity, which, in turn, leads to a rediscovery and redefining of one's individuality (and for some people, this will be a first-time discovery). So it is necessary to leave a certain symbiosis with another human being and to enter the space of one's own loneliness and solitude. The time and space of solitude and loneliness are needed to be able to gain a new understanding of oneself, of one's feelings and experiences. It is a space of solitude whereby we are allowed to reflect on who we are and what we want - to see and experience oneself separately - as opposed to in relation to another human being. The understanding of the self, which can only take place in the space of solitude, as if in separation from others, is indispensable to be able to understand and accept one's partner for who he or she really is. Therefore, first of all, a person should get to know and understand themselves, and only once they are armed with this knowledge, gained in the space of solitude, will they be able to establish a responsible relationship with another human being.

Jesper Juul repeatedly emphasised that the well-being of parents is a very important variable for the well-being of their children. Investing time and energy in the relationship with your partner does not mean that this time is being taken away from your children, but it is rather to be perceived as an investment in their happiness. This is in line with the parents first philosophy. On psychological and pedagogical grounds, there is no doubt that the basic family system is that of parents (de Barbaro, 1997, pp. 45-55). When analysing Juul's texts, one could even venture out one step further. For the parents' system and their relationship to 
be satisfactory, the philosophy of myself first needs to be recognised and implemented. Only once a person familiarises themselves with their own self, only upon liking oneself and accepting oneself, only upon learning how to take care of one's individual well-being, can a person enter a relationship with another human being with full responsibility. Maintenance of the space of solitude is indispensable for the implementation of the myself first philosophy.

In this context, it would be worthwhile to remark on Juul's observation that people are usually raised to always prioritise the community. "Therefore, we mistakenly believe that our marriage is on shaky grounds if we dine separately or sleep in different bedrooms. One has to unlearn that. What we consider appropriate for our family is good, as long as it suits all of its members (...)" (Juul, Øien, 2012, p. 219). The implementation of the myself first philosophy within the space of solitude is not an act of selfishness, it is not an act against the community, but, paradoxically, it actually serves the community. An analysis of Juul's work in this respect, may prompt us to draw the following conclusion: only if a person feels good in their own company, and only once they truly know themselves (their emotions, limitations, desires, etc.) - which is possible to attain in the space of solitude - only then do they contribute to the satisfactory existence of the family community.

Thus, the employment of myself first strategies contributes to a satisfying parents first, which in turn directly affects the quality of relationships within the parental system (Juul, 2018).

Juul's views on intimate relationships are consistent with the psychological concepts of mature love (Wojciszke, 2010). Two mature people deciding to share their life with one another do not become one being - a monad. They always remain separate entities. No two people in the world are the same, there are no two people who would choose to react in the same way in a given situation, who think the same, or feel the same. Moreover, in psychological terms, it is also impossible to be so close to another person as to become one. People are always different and lonely to some extent. The idea that when in a relationship, you always remain lonely to some extent is implicit in the works of Jesper Juul. Furthermore, this is natural and beneficial. Accepting the fact that our partner is different from us, that they think, feeland react differently, that theyare a self-contained being, and recognising our own separateness, as well as the fact that there will always be non-transferable areas of "I", is indispensable for a harmonious life together (Juul, 2018, pp. 13 - 41). Empathy, which will be discussed later on in the text, is very helpful in the process of accepting the otherness of one's partner.

Therefore, solitude in a relationship with another person not only does not contradict the quality of that relationship, but it actually contributes to its strengthening and satisfactory duration. Constructive solitude in a relationship has two faces: on the one hand, it consists in getting to know oneself, i.e. being in living communion with oneself (with one's emotions, thoughts, motives, etc.), and on the other hand, it implies accepting the fact that 
the partner also has their own space of solitude, which is different from ours and inaccessible to us - accepting that our partner is a separate human being. The experience and acceptance of these two faces of loneliness allows one to build a mature relationship with one's partner.

\section{Solitude Conducive to the Development of a Child in the Family}

Modern parenting in Western culture tends to be paedocentric. Sometimes children receive excessive attention and interest from adults. Jesper Juul argues that children need a space of solitude from their parents in order to grow. In his own words: "In my opinion, the greatest loss suffered by children over the last three decades is the fact that they have no free time from their parents. There is no longer a tree in the yard where they could be left alone" (Juul,Øien, 2012). It is tiring and stressful for children to be constantly in the centre of their parents' attention. Naturally, children need parental interest and quality time spent together, but they also need a space of solitude, in which to develop. One could venture a statement that the existence of solitude of subsystems is beneficial to the healthy functioning of the family. Thus, it is implied that the time when all the individual subsystems of the family focus on themselves is important and, paradoxically, it proves to be bonding in the scale of the entire family. In practice, this means that it is vital for parents to focus on their partner relationship, rather than spending all of their emotional resources only on their children. It is paramount for children to be granted a time when they may focus on matters that are important exclusively to them only, without the hovering presence of their parents. There is a need for spaces of solitude in which individual family subsystems can consolidate and strengthen themselves internally. According to the systemic understanding of the family unit, the stronger an individual is, the stronger the community that this individual creates. Strengthening individual family subsystems within their spaces of solitude serves to empower the family system as a whole (Juul, 2013, pp. 51 - 84).

Speaking in pragmatic terms, a certain dose of loneliness is required to develop selfsufficiency in a child, an adolescent and an adult. It is commonly accepted beyond a shadow of doubt that independence is a skill whose mastering should be supported in various dimensions of life and at its various stages. Perhaps the striving to achieve independence is particularly perceptible in the early childhood, when children want to perform many activities alone, without the participation of their parents or anyone else, for that matter, and according to their own idea and plan. Similarly, teenagers wish to act on their own volition, only in more momentous matters. They want to make decisions and act on their own.

Jesper Juul clearly indicates that it is beneficial for parents to allow their children to enjoy such solitude, while, at the same time, still being available for their children when they ask for help. Responsibility for one's own life, self-confidence and the belief in one's competence and skills can only develop within the realms of independence and solitude. In 
this case, it can be said that the fruit of solitude is self-reliance, which in turn gives rise to responsibility. This triad: solitude - independence - responsibility - constitutes personal maturity (although, of course, they do not exhaust this term).

The entry of children into the teenage period of puberty marks a significant change in intra-family relationships. Jesper Juul observed that "we should know [as parents - ER] that our role as educators comes to an end when the child turns ten or eleven" (Juul, Øien, 2012, p. 150). This does not mean, however, that adolescent children no longer need their parents. They do. But they commence a period of their life in which being alone with oneself, and often in opposition to one's parents, is a necessary element in the development of one's own identity. Juul further notes that "a young person leads as if two separate lives: one on the social level, and the other - profoundly experienced - on the existential level" (Juul, Øien, 2012, p. 166). Adolescence is a time of a special kind of loneliness - both ofthe young person in question, as well as that of their parents. Allowing a teenager to be alone away from their parents, and granting them the freedom to be independent is, in fact, an investment in the development of their maturity. The basis for placing a teenager in the space of their loneliness is the belief in their inherent skills and their responsibility, as well as the readiness to accept the parental anxiety and concern that are associated therewith (Juul, 2014, pp. 13, 85-119).

In addition to the example of one's own life, an important way to invite a child into the space of their solitude is to stimulate their reflectiveness. This is achieved by talking about what the child likes, why this, and not something else, what they think about a topic, what their take is on the current events, and what they feel in certain situations. These types of conversations are a great opportunity for a child to go beyond the clichéd thinking and to enter the world of their own thoughts and feelings, which build the space of their solitude from within.

The modern Western world is filled with stimuli. On the one hand, they can make it difficult to enter one's space of solitude, while, on the other hand, they may propel one straight into the abyss of isolation. Jesper Juul notes that the people of today, and especially children, need to experience more silence and boredom. Silence aids oneself in a creative experience of solitude, while when bored, a person makes more "own" choices than when being a mere recipient of impressions from the outside. Meditation is also useful, which helps one become mindful of one's thoughts and feelings (Juul, Øien, 2012, pp. 258-259).

So far, we have discussed the psychological dimension of loneliness and solitude. But it is also important for a household to contain physical spaces where the experience of psychological loneliness is rendered feasible. They do not have to be spacious, but it is vital for every household member to feel that if they need to be alone, they have their own spot where they can go - that they have a space to call their own and where, instead of all the external hum, they can actually hear themselves. 
When it comes to solitude, be it that of parents and/or that of children, it serves to build the inner integrity of a person. It is protected by personal boundaries (both physical and mental ones). Integrity leads to authenticity and responsibility for oneself and, ultimately, it allows one to create a community based on empathy, respect and mature love (Juul, 2013).

\section{Destructive Loneliness, i.e. Isolation}

Equally as in the case of intimate partnerships and parental relationships, loneliness and solitude bear development potential. Isolation on the other hand, is an obstacle on the path to personal growth and constitutes a negation of relationships. In Juul's pedagogy of family relationships, solitude does not break relationships, quite on the contrary - it precedes and strengthens them. Isolation, on the other hand, is a denial of being in a relationship and carries with it a serious psychological burden.

When does isolation occur in the family? Whenever being with oneself, in contact with one's own "I" entails a simultaneous inability to enter into a relationship with another person. The family ought to be a relational place by definition. Isolation in the family takes place when a person, while not entering into a relationship with another human being, is also unable to enter into a relationship with themselves at the same time. They then get stuck, as if in a vacuum. Such incapacity, or inability to enter into a relationship with one's "I" is a complex psychological issue. At this point, it will suffice to say that such situations in family life are bound to occur and, moreover, they may be caused by inappropriate reactions of parents towards their children. It is then advisable for the entire family to seek professional therapeutic help.

Isolation may appear in selected areas of family life, although it usually seems to have a global impact on the entire family unit; it may not be so initially, but it definitely becomes a global issue at some stage. The first phase of a love relationship, where the risk of isolation is particularly high, is the birth of the first child. A clear focus on the newborn child is natural and necessary; however, having a child does not stop the parents from being intimate partners for each other and their needs do not disappear from this area of life. A special bond with the child is inherent in motherhood. The father builds relations with his offspring in a different way. The bond between the father and the child depends both on the attitude displayed by the man and the woman. Different scenarios of isolationmay unfold in this new situation in families, but suffice it to say that the reason for this state of affairs may lie on the side of the woman, the man, or both of them (Juul, Øien, 2012, p. 64).

It is not beneficial for the children of a complete family unit if only one parent participates in the upbringing process, while the other shrinks from this responsibility. It so happens that this is a consequence of the parent's own isolation, experienced during this first 
stage of the child's life. A child needs a relationship with both the mother and the father. The word relationship is key here. The lack of a relationship with a parent, and with both parents in particular, inevitably leads children to isolation. As observed by Jesper Juul: “Overall, an insufficiently strong connection between parents and children - both in the past and today causes some children to feel rootless, restless, and changeable in their conduct. Some of them tend to feel hopeless, and are rather quiet and introverted" (Juul, Øien, 2012, p. 68). The lack of experience of safe relationships makes it impossible for an individual to be at ease with themselves in a calm and affirmative way, and it leads to isolation, and to a lack of understanding of oneself, whereby being with oneself is associated not with peace but with pain.

In the case of intimate relationships, isolation may appear in some areas of life, e.g. in the area of parenting, when only one of the parents is responsible for this process. If such a state of affairs is not a conscious choice of the partners, this may be acceptable from the perspective of adults, but if it happens against the will of one of the caregivers, then isolation will be at play. At the same time, it should be emphasised, following Jesper Juul's optics, that it is always better for children, if both parents participate in the upbringing process (Juul, 2012).

Juul wrote that it what usually happens in families is that a child has a special, unique bond with one parent, and that this bond is more intense than the one developed with the other caregiver. In the opinion of the educator, this is a completely natural phenomenon (Juul, 2018, pp. 13 - 41). However, it may be difficult to accept for a parent whose bond with a given child does not possess this unique quality. A subjective feeling of isolation may then arise - both in the relationship with the partner and in the relationship with the child. Of crucial importance here, if we wish to avoid this mental state, is the awareness that relationships are incomparable, and that they have variable dynamics, and that a more intense relationship with one parent does not question the quality of the relationship with the other caregiver.

One of the distorted forms of solitude in the family is hiding - be it of something, or one's true self. If loneliness, as experienced by a family member, means that he or she is hiding their true self or concealing something from the rest of the household, then this is an indicator of an incorrect and unwholesome relations in the family. If a person keeps a part of themselves hidden from others, it probably means that the unveiling of this feature would be associated with a negative experience - such as rejection, criticism and mockery (although this is not always the case). Therefore, the motivation to experience solitude is crucial here: whether a person wishes to experience it or is obliged to experience it for some reason. If they have to experience it, then solitude turns into loneliness and isolation. In other words, solitude in a family system has a developmental value when it is surrounded by safe relationships with other family members. 
In his work, Jesper Juul focused on an affirmative approach to families, unveiling their resources, their potential and intrinsic values. Juul's body of work does not feature a lot of content explicitly referring to threats to family life, including isolation. One issue, however, merits special attention. Childhood isolation and loneliness can occur whenever children start bearing on their shoulders the weight of matters which should be the responsibility of their parents. In pedagogy and psychology, this phenomenon is referred to as parentification (Rostowska, Borchert, pp. 5 - 21; Schier, 2016). Juul figuratively compared the role of a parent to that of the leader of the herd (Juul, 2017). The parent is responsible for the correct functioning of the family. If a child takes over the parental responsibility, they thus enter into the space of isolation, whereby the greater the isolation, the greater the responsibility the child needs to shoulder. Oftentimes, serving as a visible symptom of this type of isolation is the child's aggression - directed inwards or outwardly towards the parents or other persons (Juul, 2013a, pp. 51-65).

It should also be clearly emphasised, following the pertinent remarks of Jesper Juul that the responsibility for the quality of family relationships lies solely with the parents, and not the children. If a child is suffering from isolation, the parents are to be held responsible for this state of affairs (Juul, Øien, 2012, p. 80).

\section{The Relationship-Building Power of Solitude in the Family}

"Setting boundaries and designating one's own space is an important element of being together and it also poses the greatest challenge for adults" (Juul, 2020, p. 101). There are boundaries within the family unit - the personal boundaries of family members and the boundaries of the family as a whole. Juul pays special attention to the former of the two elements. Each person has their own personal limits, both physical and mental ones. It is behind the personal boundaries of parents and children that their own, personal space extends itself - the space of solitude. That is the space where an individual sets their own laws, rules and regulations at their own discretion - a space where they do what they see fit, being the lord and master of this space where they are themselves - their true self. This is a private and personal world. This is a very positive and affirmative view of solitude. Surrounded by its boundaries, solitude is a space of one's own inner world, which can be arranged as per one's desires. According to Juul, it is an important parental task to teach children that they can have this space and that they may use it creatively. Teaching them that this is their space and that they get to set its limits. Being alone is not a punishment. It is a time and place to get to know one's own world, where we can make it true and shape it according to our concept of to fulfil our potential. It is an art and an important mission for parents to know and respect their own boundaries, to use the solitude within these 
boundaries and to teach their children how to do the same (Juul, 2020, p. 46; Juul, Øien, 2012, p. 208).

The issues of boundaries and solitude are closely interwoven. Within one's own boundaries, an individual gets to experience solitude. It is a space where they can move independently and on their own, determining the shape of the boundaries from the inside. They decide on their own discretion how wide the range of their solitude will be. Juul argues that parents and other adults should respect and obey their child's arrangements. Such an attitude helps to strengthen the child's self-esteem, the importance of which cannot be overestimated in terms of building relationships with others. Only when the boundaries set by the child are respected can they develop relationships with others responsibly. In the humdrum everyday family life, this may manifest itself in such conduct as: respecting the refusal to hug someone, respecting the request not to enter the bathroom while bathing, or accepting the fact that a saddened child, after returning home from school, does not wish to talk about what he or she is currently experiencing. The optimal reactions should boil down to recognising and respecting the right to solitude of each family member to the extent that he or she chooses to delineate their boundaries.

Every child has their own integrity, their own inner world. And it is necessary for the parents to allow the child to be alone in this world by themselves, on the one hand, while, on the other hand, it is vital for the parents to be interested in the child's inner world, and to enquire about it with curiosity. This will allow them to get to know their own child - their thoughts, feelings and needs. One may not intrude on another person's solitude without being invited in first. So it is important for the child to know that he or she is the lord and master of their solitude, and that this particular space belongs to them, and to them only, but that they are not condemned to live in it, that they may choose to share it with their parents at any time - if they so wish and require (cf. Juul, Øien, 2012, p. 82).

Solitude in children is also related to experiencing certain emotions, mainly the unpleasant ones, such as anger or sadness. According to Juul, it is very wise to allow children to experience emotions in a space of solitude, e.g. when they run to their room to cry alone. However, it is a good idea to stay in the area to accompany the child when they need it. One may assure the child of one's readiness to talk with them or to hug them when the child wishes to do so. But it is advisable to give the child a chance to meet their own emotions, which is paramount for their personal growth, as well astheir mental well-being it is good to allow them to be able to acquaint themselves with their own selves, to get to know and accept what is currently occurring in them as a human being (Juul, 2020, pp. 64 $65)$.

Mark Twain wrote: "There is no loneliness worse than not feeling at ease with oneself." According to Twain, parents who fail to accept their child, or be mindful of their individuality and their resulting needs, have the power to condemn them to the worst type 
of loneliness. However, they also have the power to make the child discover their own inexhaustible sources of might, wisdom and happiness in their own space of solitude.

Jesper Juul saw an undeniable value in empathy. "Empathy is a state in which our being at ease with ourselves is expressed through the contact with other people" (Juul, Jensen et al., 2018, p. 7). "Only a person who feels safe in their own company and has an emotional contact with what makes up their existence somewhere innermost - only such an individual is able to create deeper connections with other people and rediscover themselves continuously in a complex world of constant change, in which it is increasingly difficult to find one's own place and role" (Juul, Jensen and in., 2018, p. 6). Empathy is a way to establish relationships with oneself and other people.

The relationship-building power of solitude lies in the fact that thanks to this alone time, an individual may get to know themselves, and find out who they actually are, what their wants are, and what they do not want, what they may accept and what they deem unacceptable, what they wish to change and what they wish to keep unchanged. A true relationship can only exist between true, real, concrete persons, between "I" and "you" as it is at the given moment (cf. Bubber, 1992).

If an individual conceals who and what they are, or plays a role behind poses and images, then no personal relationship with another person may ever occur. Juul makes an unequivocal statement that the most important thing for the wellness of family relationships is being authentic. This, in turn, is possible when we choose to enter the space of solitude, getting to know and rediscovering ourselves on an ongoing basis. Because any human being is constantly undergoing a process of change and because they are incessantly facing the shifts occurring in their world and in other people, making use of the space of solitude seems to be something natural and necessary every day.

"Personal language creates good, honest and solid relationships. The old language i.e. the language of power - destroys relationships, only serving tocreate winners and losers"(Juul, Øien, 2012, pp. 185-186; Juul, 2012a, pp. 86-89). Juul's observation leads the reader to conclude that in terms of the relationship-building power of solitude, we may delimitate its two degrees. The first one has been already mentioned above - entering the space of one's solitude, experiencing and meeting one's self. The second degree consists in communicating to others what we have experienced in this space of solitude.The term "communication" is understood hereby in broad terms. It also entails a specific way of functioning, being (e.g. calm, harmonious, having patience with oneself and others), which is the result of staying in a space of solitude, and it also refers to the messages expressed explicitly (be they verbal, or non-verbal). While a way of being is not something that a person consciously undertakes, or pursues with deliberation, verbal communication, however, may pose difficulties in this respect. 
In order to take full advantage of the relationship-building power of solitude, one needs to possess the ability to communicate in one's personal language. Juul pays a lot of attention to personal language, seeing it as an important element in forging personal relationships. Personal language makes it possible for two individuals to actually meet. When using their personal language, the parent does not hide behind the façade of generally accepted rules, social norms, criteria of good and bad upbringing, but they are communicating what they want, expect, as well as what they can acceptand what they find unacceptable. A rather enigmatic message (in the eyes of the child): "Children cannot go home from school alone" could be worded in the following manner in the personal language "I don't want you to come home from school alone because I think it's dangerous."

Similarly, among romantic partners, the message expressed in the personal language "I love you and I want us to spend Saturday evenings together" can successfully replace the moralising tone of "People who love each other should spend time together". Juul argues that children have a natural competence to express themselves in their personal language. Unfortunately, for many decades, parenting strategies were based on arbitrarily imposed standards, rules, and indisputable principles, which only served to weaken this natural competence. Adults, wishing to express themselves in their personal language, must acquire this competence anew. In Juul's own words: “Unfortunately, we were taught this incorrectly from the start. We were taught that saying 'I' is egocentrism, while this is actually a very socially healthy conduct" (Juul,Øien, 2012, pp. 220-221; Juul, 2014, pp. 20-28). Personal language, the source of which is located in the space of human solitude, is the key to forging personal relationships with others (Juul, 2016, pp. 65-75).

Getting to know oneself in the space of solitude and then acquiring the ability to express oneself in one's own personal language leads to openness. When talking about oneself, a person opens up to whomever they are speaking with. This moment of opening up, revealing oneself to another person is crucial for establishing a relationship.

Therefore, it is important to have an affirmative attitude to solitude within the family unit, and to accept loneliness as a space that serves the good of individual family members, which, in turn, is the foundation of the well-being of the family as a whole. According to the systemic understanding of the family, a change in one family member causes an alteration in all other family members (Drożdżewicz, 1999, pp. 11-12). Juul also clearly states that in what we call parenting in pedagogy, the example of parents' own lives is the most important factor. This is demonstrated by the following, among others, of Juul's observations: "Children copy the behaviour of adults" (Juul, Øien, 2012, p. 202), or "The quality of individual and community life of adults is decisive here. Adult life has a greater impact on children than any conscious attempts and methods of upbringing" (Juul, 2011, cover page), and, finally, "What parents refer to as parenting has no educational effect. Their words fall in one ear and fall out of the other. Children don't do what we tell them to do, they do what we 
do" (Juul, Øien, 2012, p. 266). Therefore, the example posed by the parents is vital when it comes to knowing how a meeting with oneself helps us in our everyday functioning, and how solitude can be included in building more personal and responsible relationships. Serving as an example of such use of the space of solitude can be the technique of positive break proposed within the framework of positive disciplining (cf. Nelsen, 2015, pp. 175-178).

Speaking at the highest level of generality, one may also state that modern families tend to experience loneliness, i.e. they are lonely in the surrounding world. As observed by Jesper Juul - which has been corroborated by the research conducted by many scholars (sociologists, psychologists and pedagogues) - nowadays, there is no one universally recognised or even obligatory model of family functioning in the sphere of the European culture. Each family must choose the values that it will implement in its own circle. We are being spoiled for choice in terms of the possible ways of living our lives. Juul noted, however, that it is important to make a choice, rather than relying on random trends. This kind of solitude carries with it developmental and relationship-forming potential - it allows the family to consciously choose the way of life that lies in accordance with their own belief system. Nonetheless, for this to happen, this solitude of the family as a whole should be preceded by the constructive solitude of each individual family member, especially that of the parents, with the inner recognition of what is personally important to them.

This type of solitude in choosing the path of life may be experienced as difficult, it is associated with a burden of responsibility, but it undoubtedly carries within it a relationshipcreating potential. An opposing situation is presented by the issue of the isolation of the entire family, which may also occur as a result of socio-cultural shifts. Urbanization, the ubiquitous presence of the two-career marriage model, and the institutionalization of childcare, may contribute to the weakening of the family's relations with other families. Parents are less and less able to take advantage of the daily care provided by other family members, as it is increasingly less frequent for families to share households with the older generations; due to the multiplicity of roles played by modern parents, contact with other families also gets limited. All of the above, in combination with many other factors not mentioned herein, may lead to the distinct possibility of occurrence of the phenomenon of isolation of the family itself, understood here as the need to rely solely on itself, being devoid of close relationships with other people or other families. Seen in this light, the family becomes a lonely island floating on the restless sea of shifting trends and beliefs. In the circle of social sciences, more and more attention is paid to the role of the immediate family environment with regard to its well-being. This is sometimes expressed in the parents' language with the statement that $a$ whole village is needed to raise one person. Nowadays, more and more families live as if in the desert land of big cities.

The isolation of a family whose member suffers from a chronic or incurable disease can be particularly dramatic. Such family is then at a high risk of directing all of its activities 
inward, and the immediate environment of this family (often due to ignorance of how to act, and / or a lack of sensitivity or due to embarrassment) will not seek opportunities to enter into a personal relationship with this family. Juul strongly emphasises the role of the support network as a counterbalance to isolation suffered by families burdened with a chronic disease of one of their members (Juul, 2019, pp. 80-90).

\section{Conclusion}

In summary, what constitutes the essence of family life is love. Solitude is present in families in various contexts and with varying intensities. It is important to recognise its presence and significance, and it is crucial to learn how to use solitude for the benefit of all family members and to safeguard the well-being of the family as a whole. For love and in the name of love. The question remains: How do we do it? In his book entitled "On Boundaries. Competent Relationships with a Child" (Juul, 2020, p. 71) Jesper Juul observed the following: "The lack of a method is a characteristic feature of all relationships that are based on mutual love. Certain courses of action can, of course, be outlined (...), but there is no method as such being implemented". Members of each family have the opportunity to develop their own way of experiencing solitude, based on the respect and recognition of the personal dignity and individuality of each family member.

In Jesper Juul's pedagogy of family relations, adults and children should be treated equally- that is to say: with respect. Also in the context of their need for solitude.

\section{Bibliography:}

Bubber, M. (1992). I and Thou. A Selection of Philosophical Writings, Polish translation by J. Doktór, Warsaw: Instytut Wydawniczy "Pax".

de Barbaro, B. (1997). Structure of the Family, (in:) B. de Barbaro (ed.), Introduction to the Systemic Understanding of the Family, 45-55, Kraków: Jagiellonian University Press.

Drożdżewicz, L. (1999). General Systems Theory, (in:) B. de Barbaro (ed.), Introduction to the Systemic Understanding of the Family, 9-18, Kraków: Jagiellonian University Press.

Juul, J. (2011). Your Competent Family, Polish translation by D. Syska, Podkowa Leśna: Mind.

Juul, J. (2012). Your Competent Child, Polish translation by B. Hellmann, B. Baczyńska, Podkowa Leśna: Mind.

Juul, J. (2012a). To Be a Husband and a Father, Polish translation by D. Syska, Podkowa Leśna: Mind.

Juul, J. (2013). Living in a Family. Values in Parenthood and Partnership, Polish translation by D. Syska, Podkowa Leśna: Mind.

Juul, J. (2013a). Aggression - A New Taboo? Why Do We and Our Children Need It? Polish translation by D. Syska, Podkowa Leśna: Mind. 
Juul, J. (2014). Teenagers. When Does Upbringing End? Polish translation by D. Syska, Podkowa Leśna: Mind.

Juul, J. (2016). Instead of Parenting. On the Strength of the Relationship with a Child, Polish translation by D. Syska, Podkowa Leśna: Mind.

Juul, J. (2017). Parent as the Leader of the Herd. Loving Leadership in the Family, Polish translation by D. Syska, Podkowa Leśna: Mind.

Juul, J. (2018). Being Together. A Book for Couples. Polish translation by D. Syska, Podkowa Leśna: Mind.

Juul, J. (2019). Family and Child with a Chronic Disease. Polish translation by A. Schönfeld. Podkowa Leśna: Mind.

Juul, J. (2020). On Boundaries. A Competent Relationship with a Child. Polish translation by D. Syska, Podkowa Leśna: Mind.

Juul, J., Jensen, H., Høeg, P., Hildebrandt, S., Stubberup, M. (2018). Empathy: It Strengthens the Children and Keeps the Whole World Together. Polish translation by D. Syska. Podkowa Leśna: Mind.

Juul, J., Øien, M. (2018). Space for the Family. Polish translation by D. Syska, Podkowa Leśna: Mind.

Kulig, A. (2014). Me-You-Community. Loneliness as a Strategy of Exclusion? Zeszyty Naukowe Centrum Badań im. Edyty Stein, 12, 237-248.

Nelsen, J. (2015). Positive Disciplining. Polish translation by A. Czechowska, A. Rosiak, Warsaw: CoJaNaTo.

Rostowska, T., Borchert, J. (2016). The Process of Parentification in Systems Theory, Roczniki Pedagogiczne, 8, 5-21.

Salamucha, A. (2004). Definitions of Parenting in Pedagogical Literature, Roczniki Nauk Społecznych KUL, vol. 2.

Schier, K. (2016). Adult Children: Psychological Problems of Role Reversal in the Family, Warsaw: Scholar.

Wałejko, M. (2007). Solitude and Isolation - Personal Existential States of the Human Being. Ethical-Metaphysical Analysis, Roczniki Nauk Społecznych, vol. XXXV, issue 2, 45-66.

Wojciszke, B. (2010). The Psychology of Love, Gdańsk: GWP.

\section{Websites:}

http://www.family-lab.pl/jesper-juul/, access: 11.08.2020. 